\title{
Discovery of genes from feces correlated with colorectal cancer progression
}

\author{
CHIA-LONG LEE ${ }^{1,2,5}$, CHI-JUNG HUANG ${ }^{3,4,5}$, SHUNG-HAUR YANG ${ }^{6,7}$, CHUN-CHAO CHANG ${ }^{1,8}$, \\ CHI-CHENG HUANG ${ }^{1,5,9,10}$, CHIH-CHENG CHIEN ${ }^{3,5,11}$ and RUEY-NENG YANG ${ }^{12,13}$
}

\author{
${ }^{1}$ School of Medicine, Taipei Medical University, Taipei 11031; Departments of ${ }^{2}$ Internal Medicine and \\ ${ }^{3}$ Medical Research, Cathay General Hospital, Taipei 10630; ${ }^{4}$ Department of Biochemistry, National Defense Medical Center, \\ Taipei 11490; ${ }^{5}$ School of Medicine, Fu Jen Catholic University, New Taipei 24205; ${ }^{6}$ Department of Surgery, \\ Taipei Veterans General Hospital, Taipei 11217; ${ }^{7}$ School of Medicine, National Yang Ming University, Taipei 11221; \\ ${ }^{8}$ Department of Internal Medicine, Division of Gastroenterology and Hepatology, Taipei Medical University Hospital, \\ Taipei 11031; ${ }^{9}$ Graduate Institute of Biomedical Electronics and Bioinformatics, National Taiwan University, Taipei 10617; \\ ${ }^{10}$ Department of General Surgery, Sijhih Cathay General Hospital, New Taipei 22174; \\ ${ }^{11}$ Department of Anesthesiology, Sijhih Cathay General Hospital, New Taipei 22174; ${ }^{12}$ Department of Nursing, \\ Ching Kuo Institute of Management and Health, Keelung 20301; ${ }^{13}$ Department of Internal Medicine, \\ Sijhih Cathay General Hospital, New Taipei 22174, Taiwan, R.O.C.
}

Received May 5, 2015; Accepted July 20, 2016

DOI: $10.3892 / 01.2016 .5069$

\begin{abstract}
Colorectal cancer (CRC) is considered to develop slowly via a progressive accumulation of genetic mutations. Markers of CRC may serve to provide the basis for decision-making, and may assist in cancer prevention, detection and prognostic prediction. DNA and messenger (m)RNA molecules that are present in human feces faithfully represent CRC manifestations. In the present study, exogenous mouse cells verified the feasibility of total fecal RNA as a marker of CRC. Furthermore, five significant genes encoding solute carrier family 15 , member 4 (SLC15A4), cluster of differentiation (CD)44, 3-oxoacid CoA-transferase 1 (OXCT1), placenta-specific 8 (PLAC8) and growth arrest-specific 2 (GAS2), which are differentially expressed in the feces of CRC patients, were verified in different CRC cell lines using quantitative polymerase chain reaction. The present
\end{abstract}

Correspondence to: Dr Ruey-Neng Yang, Department of Internal Medicine, Sijhih Cathay General Hospital, No. 2, Ln. 59, Jian-Cheng Road, Sijhih, New Taipei 22174, Taiwan, R.O.C.

E-mail: rnyangcmri@gmail.com

Abbreviations: CRC, colorectal cancer; SLC15A4, solute carrier family 15, member 4; CD44, cluster of differentiation 44; OXCT1, 3-oxoacid CoA-transferase 1; PLAC8, placenta-specific 8; GAS2, growth arrest-specific 2; Cq, quantification cycle; $\mathrm{GAPDH}$, glyceraldehyde 3-phosphate dehydrogenase

Key words: colorectal cancer, fecal RNA, solute carrier family 15, member 4 , serine/threonine kinase $17 \mathrm{~b}$, cluster of differentiation 44 , 3-oxoacid CoA-transferase 1, placenta-specific 8 , growth arrest-specific 2 study demonstrated that the mRNA level of SLC15A4 was increased in the majority of CRC cell lines evaluated (SW1116, LS123, Caco-2 and T84). An increased level of CD44 mRNA was only detected in an early-stage CRC cell line, SW1116, whereas OXCT1 was expressed at higher levels in the metastatic CRC cell line CC-M3. In addition, two genes, PLAC8 and GAS2, were highly expressed in the recurrent CRC cell line SW620. Genes identified in the feces of CRC patients differed according to their clinical characteristics, and this differential expression was also detected in the corresponding CRC cell lines. In conclusion, feces represent a good marker of CRC and can be interpreted through the appropriate CRC cell lines.

\section{Introduction}

Colorectal cancer (CRC) is considered to develop slowly via the progressive accumulation of genetic mutations $(1,2)$. Genes that regulate cell growth and differentiation must be altered in cancerous cells in the process of tumorigenesis $(3,4)$. Markers of CRC may provide the basis for decision-making regarding intensive chemotherapy or molecule-targeting drugs in CRC patients (5-7). Therefore, the identification of markers may assist in cancer prevention, detection and prognostic prediction $(5,8,9)$, thereby increasing survival rates (10). Molecular markers (11) have their own clinical significance in CRC (12).

In CRC, both sigmoidoscopy and colonoscopy are considered to be the gold standards regarding detection rates. However, these clinical examinations have drawbacks in terms of their risk and inconvenience $(13,14)$. Molecular markers of CRC present in the peripheral blood of patients, including carcinoembryonic antigen and carbohydrate antigen 19-9, have been discussed in numerous reports, despite exhibiting 

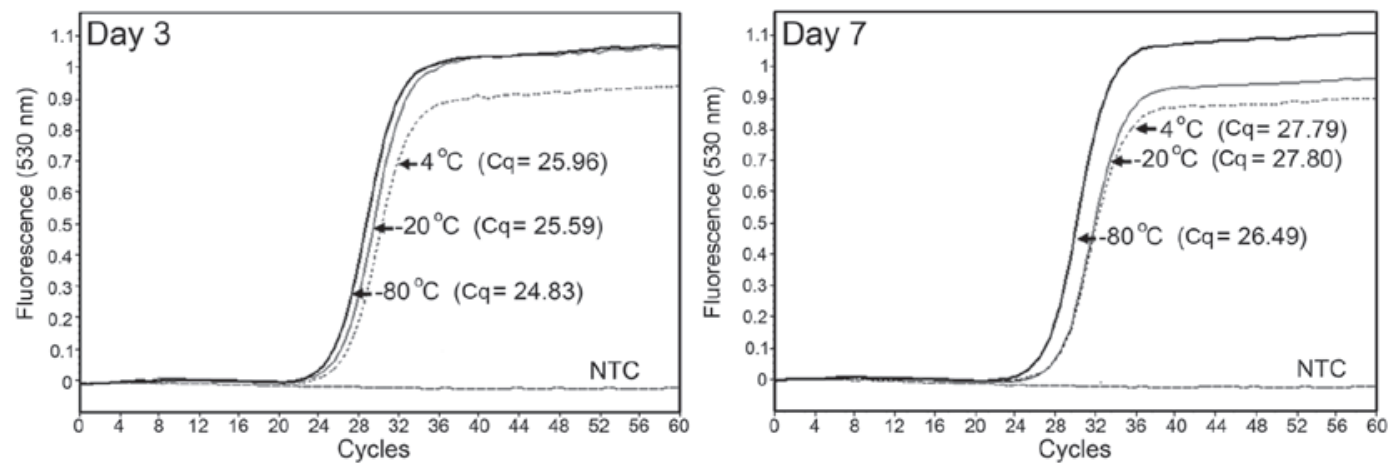

Figure 1. Quantitation of mouse $\beta$-actin in human feces. Each NIH 3T3-containing fecal sample was stored at $4,-20$ and $-80^{\circ} \mathrm{C}$ for indicated periods. Day 3 equates to a 3-day storage, and day 7 equates to 7-day storage. Total RNA of NIH 3T3 cells in human feces was extracted and reverse transcribed into complementary DNA. The Cq value was used to indicate the expression level of the detected gene. NTC, non-template control; NIH, National Institutes of Health; Cq, quantification cycle.

poor specificity (15). In addition to the fecal occult blood test, the molecular detection of CRC using human feces has attracted attention in recent years (16-18). In fact, feces gather shedding cells from the colonic tract, including CRC cells, and respond to localized malignance $(7,19,20)$. Not only DNA but also messenger (m)RNA molecules that are present in human feces faithfully represent CRC manifestations $(17,21-24)$. For this reason, human feces are potentially appropriate material to gain an understanding of CRC development $(25,26)$.

Gene expression is used for classifying tumors or predicting prognoses (27). The active genetic molecules that are differentially expressed in feces may be non-invasive candidates to indicate the pathogenic processes that underlie pharmacological responses. Studies of active genes in human feces have revealed specific molecular signatures of different CRC patients $(28,29)$. Previously, several genes were reported as having differential expression in the feces of CRC patients $(21,30)$. Furthermore, a number of these genes were correlated with cancer $(20,21,24,31-34)$. The expression of the most significant of these genes must be characterized and explored in CRC cells $(21,35,36)$.

To verify the clinical credibility of fecal molecules, the present study first assessed the stability of mRNAs from human fecal samples that were stored under different conditions. Subsequently, the most significant genes in CRC were verified using quantitative polymerase chain reaction (qPCR) in different CRC cell lines. The present results may shed light on the selection of the best treatment option for individual patients according to their significant fecal molecules.

\section{Materials and methods}

Quantitation of the mouse $\beta$-actin gene in human feces. To simulate the sloughed colonic cells present in human feces, $1 \times 10^{4}$ mouse embryonic fibroblast cells [National Institutes of Health (NIH) 3T3 cells, gifted by Dr Shih-Ming Huang, National Defense Medical Center, Taipei, Taiwan] were added into $0.5 \mathrm{~g}$ of feces from a healthy volunteer (a 37-year-old male). The present study was approved by the Institutional Review Board of Cathay General Hospital (Taipei, Taiwan) as a research study. Each NIH 3T3-containing fecal sample was stored under different conditions (Fig. 1) in our specific buffer (30). The fecal total RNA was extracted and reverse transcribed into complementary (c)DNA as detailed in our previous reports $(21,30)$. The mouse $\beta$-actin gene (NM_007393) was specifically quantified by qPCR on a LightCycler 1.5 instrument (Roche Diagnostics GmbH, Mannheim, Germany), according to the standard protocol (37). The primers and the TaqMan ${ }^{\circledR}$ probe used for quantifying the mRNA levels of mouse $\beta$-actin are listed in Table I. In addition, the quantification cycle $(\mathrm{Cq})$ value was used to indicate the expression level of the detected gene (38).

Colonic cell lines and cell culture. In the present study, one normal colonic cell line [CCD-18Co, American Type Culture Collection (ATCC) CRL-1459], three early-stage CRC cell lines (SW1116, ATCC CCL-233; LS123, ATCC CCL-255; and SW480, ATCC CCL-228; ATCC, Manassas, VA, USA), and three late-stage CRC cell lines (SW620, ATCC CCL-227; Caco-2, ATCC HTB-37; and T84, ATCC CCL-248; ATCC) were used $(39,40)$. In addition, one metastatic CRC cell line [CC-M3, Bioresource Colletion and Research Center (BCRC) 60450] was purchased from BCRC (Hsinchu, Taiwan) (41). With the exception of SW1116, SW480 and SW620, which were cultured in Leibovitz's L-15 Medium in a non- $\mathrm{CO}_{2}$ incubator, other cells were cultured at $37^{\circ} \mathrm{C}$ in a humidified $5 \% \mathrm{CO} 2$ incubator with the medium recommended by ATCC, such as Eagle's minimum essential medium or Dulbecco's modified Eagle's medium. All culture medium contained fetal bovine serum to a final concentration of $10 \%$.

Extraction of total cellular RNA and reverse transcription. Total cellular RNA was extracted from cultured cells using TRIzol reagent (Thermo Fisher Scientific, Inc., Waltham, MA, USA) according to the manufacturer's protocol. Subsequently, $1 \mu \mathrm{g}$ of total RNA was reverse transcribed into single-stranded cDNA using $0.5 \mu \mathrm{g}$ of oligo(dT) primer and a High Capacity cDNA Reverse Transcription kit (Applied Biosystems; Thermo Fisher Scientific, Inc.).

Quantification of the mRNA levels of target genes in cells. The genes of interest were quantified in CCD-18Co cells or in the different CRC cell lines using the TaqMan ${ }^{\circledR}$ qPCR 
Table I. Primers and TaqMan ${ }^{\circledR}$ probe for quantifying the messenger RNA levels of mouse $\beta$-actin.

\begin{tabular}{lcc}
\hline Gene (symbol) & Accession no. & Primers (5'-3') \\
\hline Mus musculus actin, beta (Actb) & NM_007393 & $\begin{array}{l}\text { F: AAGGCCAACCGTGAAAAGAT no. } \\
\text { R: GTGGTACGACCAGAGGCATAC }\end{array}$ \\
\hline
\end{tabular}

F, forward; R, reverse; UPL, Universal Probe Library.

Table II. Primers and TaqMan ${ }^{\circledR}$ probes for quantifying the messenger RNA levels of target genes.

\begin{tabular}{|c|c|c|c|}
\hline Gene (symbol) & Accession no. & Primers $\left(5^{\prime}-3^{\prime}\right)$ & UPL no. \\
\hline $\begin{array}{l}\text { Solute carrier family } 15, \\
\text { member } 4 \text { (SLC15A4) }\end{array}$ & NM_145648 & $\begin{array}{l}\text { F: GAGCAGTCACACAGACTTTGGT } \\
\text { R: CAGGAGGGTAGCTCCTTGAA }\end{array}$ & \#71 \\
\hline $\begin{array}{l}\text { Cluster of differentiation } 44 \\
\text { (CD44) }\end{array}$ & NM_001202555 & $\begin{array}{l}\text { F: CAAGCAGGAAGAAGGATGGAT } \\
\text { R: AACCTGTGTTTGGATTTGCAG }\end{array}$ & \#41 \\
\hline $\begin{array}{l}\text { 3-oxoacid CoA-transferase } 1 \\
\text { (OXCT1) }\end{array}$ & NM_000436 & $\begin{array}{l}\text { F: ACTGGGTGTGATTTTGCAGTT } \\
\text { R: GCAGCCTGGTACAAATATCCA }\end{array}$ & \#84 \\
\hline $\begin{array}{l}\text { Placenta-specific } 8 \\
(\text { PLAC8) }\end{array}$ & NM_016619 & $\begin{array}{l}\text { F: CGTCGCAATGAGGACTCTCT } \\
\text { R: CTCTTGATTTGGCAAAGAGTACAA }\end{array}$ & \#56 \\
\hline $\begin{array}{l}\text { Growth arrest-specific } 2 \\
(\text { GAS2) }\end{array}$ & NM_005256 & $\begin{array}{l}\text { F: TGGGAGAAAAGATCCTCTTCATT } \\
\text { R: TCAACAAATACCCTGCAAAAGTT }\end{array}$ & \#75 \\
\hline $\begin{array}{l}\text { Glyceraldehyde 3-phosphate } \\
\text { dehydrogenase (GAPDH) }\end{array}$ & NM_002046 & $\begin{array}{l}\text { F: CTCTGCTCCTCCTGTTCGAC } \\
\text { R: ACGACCAAATCCGTTGACTC }\end{array}$ & \#60 \\
\hline
\end{tabular}

F, forward; R, reverse; UPL, Universal Probe Library.

Table III. Genes with potentially clinical significance in feces of CRC patients.

\begin{tabular}{lcll}
\hline Comparison & Number of genes $^{\mathrm{a}}$ & \multicolumn{1}{c}{ Representative gene } & Used cell lines \\
\hline Normal $^{\text {b vs. CRC }}$ & 180 & Solute carrier family 15, & $\begin{array}{l}\text { CCD-18Co, SW1116, LS123, } \\
\text { member 4 }\end{array}$ \\
Normal vs. AJCC stage I & 167 & Cluster of differentiation 44 & CCD-18Co and SW1116 \\
Non-metastasis vs. metastasis & 9 & 3-oxoacid CoA-transferase 1 & SW480 and CC-M3 \\
Non-recurrence vs. recurrence & 22 & Placenta-specific 8 and & SW480 and SW620
\end{tabular}

${ }^{\mathrm{a}}$ Genes with differential expression were identified as $>2$-fold $(\mathrm{P}<0.05)$. ${ }^{\mathrm{b}}$ Normal, healthy controls without any CRC symptoms. CRC, colorectal cancer; AJCC, American Joint Committee on Cancer.

approach, as aforementioned. The amplification primers and TaqMan ${ }^{\circledR}$ probes from the Universal ProbeLibrary Set, Human (Roche Diagnostics $\mathrm{GmbH}$ ) used are listed in Table II. To avoid errors caused by sample-to-sample differences in RNA quantity, the normalization of each gene was performed using the level of glyceraldehyde 3-phosphate dehydrogenase (GAPDH, NM_002046). LightCycler 4.05 Software (Roche Diagnostics $\mathrm{GmbH}$ ) was used to analyze the PCR kinetics.

Statistical analysis. Gene expressions of two groups were analyzed for significance using the Student's t-test. The calculations were made with SPSS software (v.16.0; SPSS,
Inc. Chicago, IL, USA). $\mathrm{P}<0.05$ was considered to indicate a statistically significant difference.

\section{Results}

Feasibility of total fecal RNA as a marker of CRC and custom-made microarrays for CRC patients. As indicated in Fig. 1, three $\mathrm{Cq}$ values $\left(25.96\right.$ at $4^{\circ} \mathrm{C}, 25.59$ at $-20^{\circ} \mathrm{C}$ and 24.83 at $-80^{\circ} \mathrm{C}$ ) after a 3-day storage were not remarkably different to those detected at day 0 (25.61). Similar results were obtained after a 7-day storage; however, the difference was slightly larger. By applying this technique of fecal RNA purification, numerous genes that were expressed differentially 


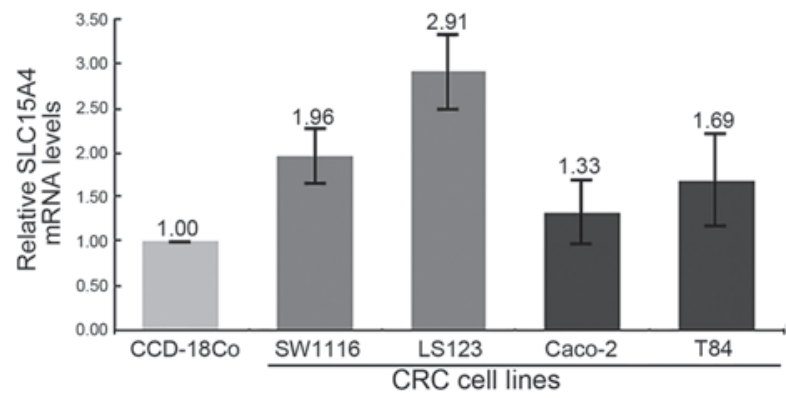

Figure 2. Relative mRNA levels of SLC15A4 in CRC cells. The expression of SLC15A4 (NM_145648) was quantified by quantitative polymerase chain reaction and normalized to the expression of endogenous glyceraldehyde 3-phosphate dehydrogenase (NM_002046). Normal colonic cell line, CCD-18Co; early-stage CRC cell lines, SW1116 (AJCC stage I) and LS123 (AJCC stage II); late-stage CRC cell lines, Caco-2 and T84 (AJCC stage IV). SLC15A4, solute carrier family 15, member 4; AJCC, American Joint Committee on Cancer; mRNA, messenger RNA; CRC, colorectal cancer.

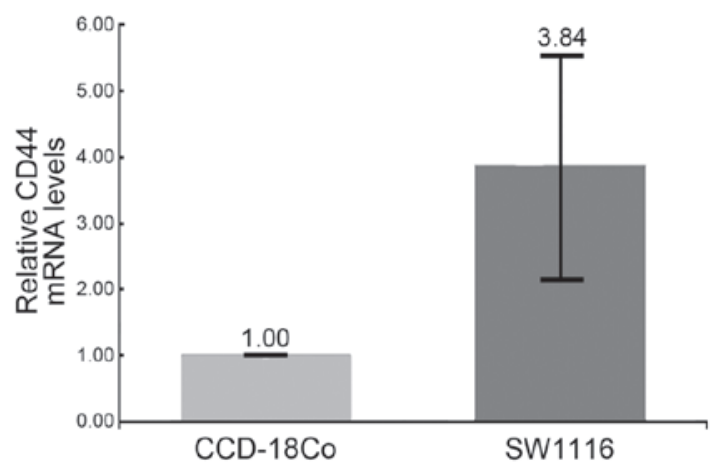

Figure 3. Relative mRNA levels of CD44 in early-stage CRC. The expression of CD44 (NM_001202555) was quantified by quantitative polymerase chain reaction and normalized to the expression of endogenous glyceraldehyde 3-phosphate dehydrogenase (NM_002046). Normal colonic cell line, CCD-18Co; early-stage CRC cell line, SW1116 (American Joint Committee on Cancer stage I). CD44, cluster of differentation 44; mRNA, messenger RNA; CRC, colorectal cancer.

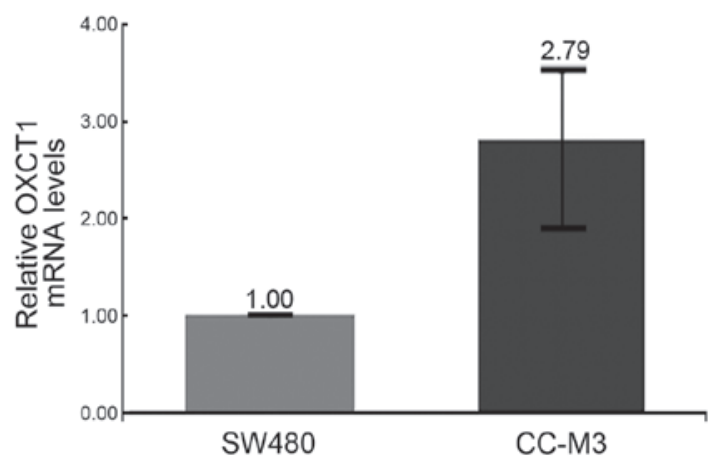

Figure 4. Relative mRNA levels of OXCT1 in metastatic CRC. The expression of OXCT1 (NM_000436) was quantified by quantitative polymerase chain reaction and normalized to the expression of endogenous glyceraldehyde 3-phosphate dehydrogenase (NM_002046). Non-metastatic CRC cell line, SW480; metastatic CRC cell line, CC-M3. mRNA, messenger RNA; CRC, colorectal cancer; OXCT1, 3-oxoacid CoA-transferase 1.

in the feces of CRC patients were identified, as assessed by analysis of whole-genome oligonucleotide microarrays (30). As summarized in Table III, genes with a significantly
A

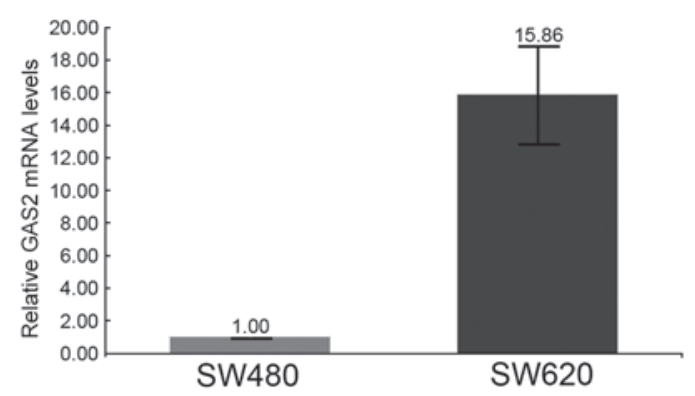

B

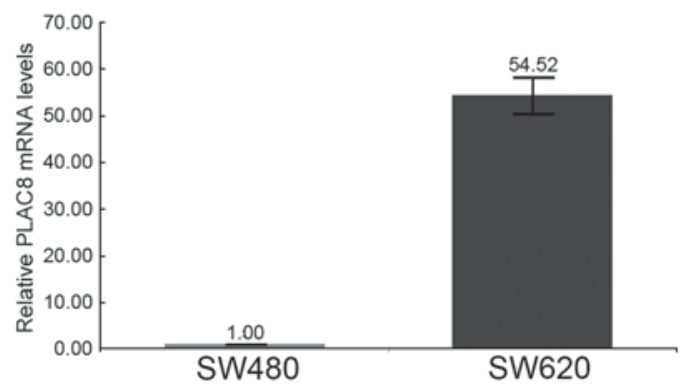

Figure 5. Relative mRNA levels of genes in recurrent CRC. (A) GAS2 (NM_005256) and (B) PLAC8 (NM_016619) were quantified by quantitative polymerase chain reaction and normalized to the expression of endogenous glyceraldehyde 3-phosphate dehydrogenase (NM_002046). Non-recurrent CRC cell line, SW480; recurrent CRC cell line, SW620. mRNA, messenger RNA; CRC, colorectal cancer; PLAC8, placenta-specific 8; GAS2, growth arrest-specific 2 .

differential expression ( $>2$-fold, $\mathrm{P}<0.05$ ) were selected from the feces of a group of 16 subjects that consisted of 5 noncancerous individuals and $11 \mathrm{CRC}$ patients at different American Joint Committee on Cancer (AJCC) stages (2 at AJCC stage I, 3 at stage II, 3 at stage III and 3 at stage IV).

Validation of genes that were differentially expressed in CRC cell lines. Partial genes that were highly expressed in the feces of CRC patients were verified using CRC cell lines (Figs. 2-5 and Table III). For example, solute carrier family 15, member 4 (SLC15A4, NM_145648) was upregulated in the majority of feces of CRC patients. The expression of SLC15A4 was also increased in four CRC cell lines (SW1116, LS123, Caco-2 and T84) at different AJCC stages compared with the normal colonic cell line CCD-18Co (Fig. 2).

To identify the initial stages of CRC, 167 genes that exhibited differential expression in early-stage CRC or in CRC patients without symptoms were selected. Among these 167 genes, a cell-surface molecule, cluster of differentiation (CD)44 (NM_001202555) was upregulated (42) in the SW1116 cell line (3.84-fold), which was previously diagnosed as AJCC stage I (Fig. 3). To date, the majority of the genetic research conducted on metastatic or recurrent $\mathrm{CRC}$ is confined to a single molecule (43-45). It is known that distant metastasis is the major cause of mortality in CRC patients (46). However, few studies have investigated the profiles of genetic variation in these CRC patients. Thus, fecal total RNA was used to distinguish metastatic or recurrent CRC patients from other CRC patients in the present study. The results revealed that one gene involved in extrahepatic ketone-body catabolism, 3-oxoacid CoA-transferase 1 (OXCT1, 
NM_000436), was expressed at higher levels (2.79-fold) in the metastatic CRC cell line CC-M3 than in the non-metastatic cell line SW480 (Fig. 4). In addition, two genes, growth arrest-specific 2 (GAS2, NM_005256) and placenta-specific 8 (PLAC8, NM_016619), which are involved in recurrent CRC, were detected in the SW620 cell line, which is the lymph-node metastatic derivative of the SW480 cell line $(47,48)$. As indicated in Fig. 5, both GAS2 (15.86-fold) and PLAC8 (54.52-fold) were upregulated in the SW620 cell line compared with the SW480 cell line.

\section{Discussion}

The differentiation of CRC patients from non-cancer individuals or CRC patients with different clinical characteristics is crucial in CRC treatment. However, the current staging system used for CRC, which is based on the tumor-node-metastasis classification, does not yield a reliable personalized prediction of prognosis (49). This can be improved by employing molecular parameters in addition to the staging system (50).

In recent years, human feces have been used as research material in CRC (51). Both fecal DNA and RNA are known to represent $\mathrm{CRC}$-related molecular targets (51-53). Our previous studies also reported various molecules that are differentially expressed in human feces (30). Significant gene profiles were acquired computationally by comparing different group settings according to clinical characteristics. In the present study, the feasibility of total fecal RNA as a marker of CRC was first verified using exogenous mouse cells. Subsequently, different CRC cell lines were used to validate the differentially expressed genes in feces. The significant molecules detected in CRC cell lines may provide novel insights into colorectal carcinogenesis and personalized prediction in a non-invasive manner using human feces.

For example, upregulation of SLC15A4 was detected in the feces of CRC patients and in CRC cell lines at different stages (AJCC stages I-IV). Expression of SLC15A4, a histidine transporter, was previously observed in the gastrointestinal tract (54). This histidine transporter coordinates mechanistic target of rapamycin-dependent inflammatory responses and may promote colitis $(55,56)$. In the present study, two early-stage CRC cell lines, SW1116 and LS123, exhibited a higher expression level of SLC15A4 than normal colonic cells and late-stage CRC cell lines. Furthermore, an anti-inflammatory function may contribute to antitumor activity (57). Thus, SLC15A4 may participate in the initial inflammation-induced colorectal dysplasia. This result may be associated with another marker, CD44, which was detected in the feces of CRC patients at AJCC stage I. CD44 is of functional importance for tumor initiation and progression in CRC (58). In another animal study, downregulated CD44 was able to reduce tumor growth significantly (59). Recently, CD44 was further proposed to contribute to targeted therapeutic strategies due to its role in sensing the extracellular environment (60). These findings are in agreement with the results obtained in the present study for the fecal samples of early-stage cancer groups and for SW1116 cells. Taken together, our findings revealed that the detection of SLC15A4 and CD44 in feces may aid to identify the initial CRC cells. Another gene that was identified in the feces of CRC patients at AJCC stage IV was OXCT1 (61-63). Increased expression of OXCT1 has been observed in numerous human cancers. As detected in the present study in metastatic CRC, a substantially elevated level of expression of OXCT1 has been reported in association with metastatic cancers $(62,63)$, which suggests that OXCT1 may be a potential marker of late-stage CRC and can be detected in feces.

In fact, the two genes involved in CRC recurrence described in the current study were also reported in other human cancers. For example, GAS2 was expressed at a high level in chronic myeloid leukemia cells, and the inhibition of GAS2 impaired tumor growth. PLAC8 was also upregulated in other human leukemic cells and induced apoptosis resistance (64). In addition, PLAC8 overexpression was further linked to intestinal stem cells in CRC (65). Our current results appear to agree with these reports due to the high expression levels of GAS2 and PLAC8 detected in the feces of relapsed CRC patients and in the recurrent CRC cell line SW620.

Genes involved in CRC tumorigenesis or with uncharacterized functions may be potential markers that could aid in CRC detection, diagnosis, treatment or prognostic prediction (66). However, upregulated genes were frequently observed during the process of CRC tumorigenesis (67). In the present study, CRC cell lines were used to validate the genes that were significantly upregulated in the feces of CRC patients. Our results suggest that $\mathrm{CRC}$ cell lines can respond to differential gene expression in feces. Thus, the present study focused on detecting fecal RNA in association with tumor initiation, recurrence and liver metastasis in CRC. Clinically, pathological factors, alone or in combination, cannot perfectly identify CRC patients or make a personalized prediction of recurrence $(49,68)$. The molecules involved in CRC pathogenesis may act as markers of early CRC diagnosis or may be used to stratify susceptible patients into appropriate screening or surveillance programs (69). In other words, the genetic understanding of CRC has led to the introduction of molecular proposals that exemplify the knowledge translated from basic science to clinical care (10). The possible clinical application of non-invasive molecules provides a useful platform in molecular medicine and translational research. Genes expressed in the feces of CRC patients varied in the present study according to the clinical characteristics of the individuals, and these differential expression levels also arose in the corresponding CRC cell lines. In conclusion, feces represent a good marker of CRC and can be interpreted using the appropriate CRC cell lines.

\section{Acknowledgements}

The current study was supported by grants (grant numbers CGH-MR-10119 and CGH MR-A10218) from Cathay General Hospital (Taipei, Taiwan).

\section{References}

1. Vogelstein B, Fearon ER, Hamilton SR, Kern SE, Preisinger AC, Leppert M, Nakamura Y, White R, Smits AM and Bos JL: Genetic alterations during colorectal-tumor development. J Engl Med 319: 525-532, 1988.

2. Jass JR: Colorectal cancer: A multipathway disease. Crit Rev Oncog 12: 273-287, 2006.

3. Kong YW, Ferland-McCollough D, Jackson TJ and Bushell M: microRNAs in cancer management. Lancet Oncol 13: e249-e258, 2012. 
4. You JS and Jones PA: Cancer genetics and epigenetics: Two sides of the same coin? Cancer Cell 22: 9-20, 2012.

5. Center MM, Jemal A, Smith RA and Ward E: Worldwide variations in colorectal cancer. CA Cancer J Clin 59: 366-378, 2009

6. Chun P and Wainberg ZA: Adjuvant Chemotherapy for Stage II Colon Cancer: The role of molecular markers in choosing therapy. Gastrointest Cancer Res 3: 191-196, 2009.

7. Matsuyama T, Ishikawa T, Mogushi K, Yoshida T, Iida S, Uetake H, Mizushima H, Tanaka H and Sugihara K: MUC12 mRNA expression is an independent marker of prognosis in stage II and stage III colorectal cancer. Int J Cancer 127: 2292-2299, 2010.

8. Kimura Y, Sumiyoshi M and Baba K: Antitumor activities of synthetic and natural stilbenes through antiangiogenic action. Cancer Sci 99: 2083-2096, 2008.

9. Watine JC and Bunting PS: Mass colorectal cancer screening: Methodological quality of practice guidelines is not related to their content validity. Clinical Biochem 41: 459-466, 2008.

10. Soreide K, Berg M, Skudal BS and Nedreboe BS: Advances in the understanding and treatment of colorectal cancer. Discov Med 12: 393-404, 2011

11. Sinicrope FA, Shi Q, Smyrk TC, et al: Molecular markers identify subtypes of stage III colon cancer associated with patient outcomes. Gastroenterology 148: 88-99, 2015.

12. Matsuda T, Chiu HM, Sano Y, Fujii T, Ono A and Saito Y: Surveillance colonoscopy after endoscopic treatment for colorectal neoplasia: From the standpoint of the Asia-Pacific region. Digestive Endoscopy 28: 342-347, 2016.

13. Blázquez $\mathrm{C}$, Geelen $\mathrm{MJ}$, Velasco $\mathrm{G}$ and Guzmán $\mathrm{M}$ : The AMP-activated protein kinase prevents ceramide synthesis de novo and apoptosis in astrocytes. FEBS Lett 489: 149-153, 2001

14. Belletti B, Nicoloso MS, Schiappacassi M, Chimienti E, Berton S, Lovat F, Colombatti A and Baldassarre G: p27(kip1) functional regulation in human cancer: A potential target for therapeutic designs. Curr Med Chem 12: 1589-1605, 2005.

15. Yang SH, Lin JK, Lai CR, Chen CC, Li AF, Liang WY and Jiang JK: Risk factors for peritoneal dissemination of colorectal cancer. J Surg Oncol 87: 167-173, 2004.

16. Huang CJ, Yang SH, Lee CL, Cheng YC, Tai SY and Chien CC: Ribosomal protein S27-like in colorectal cancer: A candidate for predicting prognoses. PLoS One 8: e67043, 2013.

17. Imperiale TF, Ransohoff DF, Itzkowitz SH, Levin TR, Lavin P, Lidgard GP, Ahlquist DA and Berger BM: Multitarget stool DNA testing for colorectal-cancer screening. NEngl J Med 370: 1287-1297, 2014

18. Ng JM and $\mathrm{Yu}$ J: Promoter hypermethylation of tumour suppressor genes as potential biomarkers in colorectal cancer. Int J Mol Sci 16: 2472-2496, 2015.

19. Giusti L, Iacconi P, Da Valle Y, Ciregia F, Ventroni T, Donadio E Giannaccini G, Chiarugi M, Torregrossa L, Proietti A, et al: A proteomic profile of washing fluid from the colorectal tract to search for potential biomarkers of colon cancer. Mol Biosyst 8: 1088-1099, 2012

20. Young GP and Bosch LJ: Fecal tests: From blood to molecular markers. Curr Colorectal Cancer Rep 7: 62-70, 2011.

21. Huang CJ, Chien CC, Yang SH, Chang CC, Sun HL, Cheng YC, Liu CC, Lin SC and Lin CM: Faecal ribosomal protein L19 is a genetic prognostic factor for survival in colorectal cancer. J Cell Mol Med 12: 1936-1943, 2008

22. Takai T, Kanaoka S, Yoshida K, Hamaya Y, Ikuma M, Miura N, Sugimura H, Kajimura M and Hishida A: Fecal cyclooxygenase 2 plus matrix metalloproteinase 7 mRNA assays as a marker for colorectal cancer screening. Cancer Epidemiol Biomarkers Prev 18: 1888-1893, 2009.

23. Hamaya Y, Yoshida K, Takai T, Ikuma M, Hishida A and Kanaoka S: Factors that contribute to faecal cyclooxygenase-2 mRNA expression in subjects with colorectal cancer. Br J Cancer 102: 916-921, 2010.

24. Yang SH, Huang CJ, Lee CL, Liu CC, Chien CC and Chen SH: Fecal RNA detection of cytokeratin 19 and ribosomal protein L19 for colorectal cancer. Hepatogastroenterology 57: 710-715, 2010.

25. Steele RJ, Kostourou I, McClements P, Watling C, Libby G Weller D, Brewster DH, Black R, Carey FA and Fraser C: Effect of repeated invitations on uptake of colorectal cancer screening using faecal occult blood testing: Analysis of prevalence and incidence screening. BMJ 341: c5531, 2010

26. Tonus C, Sellinger M, Koss K and Neupert G: Faecal pyruvate kinase isoenzyme type M2 for colorectal cancer screening: A meta-analysis. World J Gastroenterol 18: 4004-4011, 2012.

27. Raspe E, Decraene C and Berx G: Gene expression profiling to dissect the complexity of cancer biology: Pitfalls and promise. Semin Cancer Biol 22: 250-260, 2012
28. Bernal G: Use of RNA isolated from feces as a promising tool for the early detection of colorectal cancer. Int J Biol Markers 27: e82-e89, 2012.

29. Shi M, Beauchamp RD and Zhang B: A network-based gene expression signature informs prognosis and treatment for colorectal cancer patients. PLoS One 7: e41292, 2012.

30. Chien CC, Chang CC, Yang SH, Chen SH, et al: A homologue of the drosophila headcase protein is a novel tumor marker for early-stage colorectal cancer. Oncol Rep 15: 919-926, 2006.

31. Yang SH, Chien CC, Chen CW, Li SY and Huang CJ: Potential of faecal RNA in diagnosing colorectal cancer. Cancer Lett 226 55-63, 2005.

32. Chang CC, Yang SH, Chien CC, Chen SH, Pan S, Lee CL, Lin CM, Sun HL, Huang CC, Wu YY, et al: Clinical meaning of age-related expression of fecal cytokeratin 19 in colorectal malignancy. BMC cancer 9: 376, 2009.

33. Kato I, Badsha KZ, Land S, Nechvatal JM, Matherly LH, Tarca AL, Majumdar AP, Basson MD and Ram JL: DNA/RNA markers for colorectal cancer risk in preserved stool specimens: A pilot study. Tumori 95: 753-761, 2009

34. Yang RN, Yang SH, Chang CC, Chien CC, Pan S and Huang CJ: Upregulation of fecal cytokeratin 19 is associated with prognosis in older colorectal cancer patients. Genet Test Mol Biomarkers 14: 703-708, 2010

35. Liebig C, Agarwal N, Ayala GE, Verstovsek G, Tuszynski GP and Albo D: Angiocidin inhibitory peptides decrease tumor burden in a murine colon cancer model. J Surg Res 142: 320-326, 2007.

36. Wu CY, Lee WH, Wang JY, Chiang H, Chang JL, Tsai WC, Sheu LF and Jin JS: Tissue microarray-determined expression profiles of cyclooxygenase-2 in colorectal adenocarcinoma: Association with clinicopathological parameters. Chin J Physiol 49: 298-304, 2006.

37. Altangerel O, Cao S, Meng J, et al: Chronic neutrophilic leukemia with overexpression of EVI-1, and concurrent CSF3R and SETBP1 mutations: A case report. Oncology letters 10: 1694-1700, 2015.

38. Hellemans J, Mortier G, De Paepe A, Speleman F and Vandesompele J: qBase relative quantification framework and software for management and automated analysis of real-time quantitative PCR data. Genome biology 8: R19, 2007.

39. Tien LT, Chien CC, Yang SH, Lin CM, Wu YY and Huang CJ: p53-Dependent Expression of Ribosomal Protein S27-Like in Colorectal Cancer. Fu Jen J Med 8: 11-17, 2010.

40. Christensen J, El-Gebali S, Natoli M, Sengstag T, Delorenzi M, Bentz S, Bouzourene H, Rumbo M, Felsani A, Siissalo S, et al: Defining new criteria for selection of cell-based intestinal models using publicly available databases. BMC genomics 13: 274, 2012.

41. Wu CC, Tsai FM, Shyu RY, Tsai YM, Wang CH and Jiang SY: G protein-coupled receptor kinase 5 mediates Tazarotene-induced gene 1-induced growth suppression of human colon cancer cells BMC cancer 11: 175, 2011.

42. Godar S, Ince TA, Bell GW, Feldser D, Donaher JL, Bergh J, Liu A, Miu K, Watnick RS, Reinhardt F, et al: Growth-inhibitory and tumor-suppressive functions of $\mathrm{p} 53$ depend on its repression of CD44 expression. Cell 134: 62-73, 2008

43. Elzagheid A, Emaetig F, Buhmeida A, Laato M, El-Faitori O, Syrjänen K, Collan Y and Pyrhönen S: Loss of MUC2 expression predicts disease recurrence and poor outcome in colorectal carcinoma. Tumour Biol 34: 621-628, 2012.

44. Herszenyi L, Hritz I, Lakatos G, Varga MZ and Tulassay Z: The behavior of matrix metalloproteinases and their inhibitors in colorectal cancer. Int J Mol Sci 13: 13240-13263, 2012.

45. Lu Y, Jingyan G, Baorong S, Peng J, Xu Y and Cai S: Expression of EGFR, Her2 predict lymph node metastasis (LNM)-associated metastasis in colorectal cancer. Cancer Biomark 11: 219-226, 2012

46. Hur K, Toiyama Y, Schetter AJ, et al: Identification of a metastasis-specific MicroRNA signature in human colorectal cancer. J Nat Can Ins 107: 2015.

47. Bordonaro $M$ and Lazarova DL: Determination of the Role of CBP- and p300-Mediated Wnt Signaling on Colonic Cells. JMIR Res Prot 5: e66, 2016.

48. Huang CJ, Lee CL, Yang SH, et al: Upregulation of the growth arrest-specific-2 in recurrent colorectal cancers, and its susceptibility to chemotherapy in a model cell system. Biochim Biophys Acta 1862: 1345-1353, 2016

49. Miyake M, Takemasa I, Matoba R, Tanino M, Niijima S, Ikeda M, Yamamoto H, Sekimoto M, Kuhara S, Okayama T, et al: Heterogeneity of colorectal cancers and extraction of discriminator gene signatures for personalized prediction of prognosis. Int J Oncol 39: 781-789, 2011 
50. Sudoyo AW: Biomolecular markers as determinants of patients selection for adjuvant chemotherapy of sporadic colorectal cancers. Acta Med Indones 42: 45-50, 2010.

51. Carroll MR, Seaman HE and Halloran SP: Tests and investigations for colorectal cancer screening. Clinical Biochem 47: 921-939, 2014

52. Pox C: Colon cancer screening: Which non-invasive filter tests? Dig Dis 1 (Suppl 1): S56-S59, 2011.

53. Miller S and Steele S: Novel molecular screening approaches in colorectal cancer. J Surg Oncol 105: 459-467, 2012.

54. Bhardwaj RK, Herrera-Ruiz D, Eltoukhy N, Saad M and Knipp GT: The functional evaluation of human peptide/histidine transporter 1 (hPHT1) in transiently transfected COS-7 cells. Eur J Pharm Sci 27: 533-542, 2006.

55. Kobayashi T, Shimabukuro-Demoto S, Yoshida-Sugitani R, Furuyama-Tanaka K, Karyu H, et al: The histidine transporter SLC15A4 coordinates mTOR-dependent inflammatory responses and pathogenic antibody production. Immunity 41: 375-388, 2014

56. Sasawatari S, Okamura T, Kasumi E, Tanaka-Furuyama K, Yanobu-Takanashi R, Shirasawa S, Kato $N$ and Toyama-Sorimachi $\mathrm{N}$ : The solute carrier family $15 \mathrm{~A} 4$ regulates TLR9 and NOD1 functions in the innate immune system and promotes colitis in mice. Gastroenterology 140: 1513-1525, 2011.

57. Ye Q, Zheng Y, Fan S, Qin Z, Li N, Tang A, Ai F, Zhang X, Bian Y, Dang W, et al: Lactoferrin deficiency promotes colitis-associated colorectal dysplasia in mice. PLoS One 9: e103298, 2014.

58. Rao G, Wang H, Li B, Huang L, Xue D, et al: Reciprocal interactions between tumor-associated macrophages and CD44 positive cancer cells via osteopontin/CD44 promote tumorigenicity in colorectal cancer. Clin Cancer Res 19: 785-797, 2013.

59. Perez A, Neskey DM, Wen J, Pereira L, Reategui EP, Goodwin WJ, Carraway KL and Franzmann EJ: CD44 interacts with EGFR and promotes head and neck squamous cell carcinoma initiation and progression. Oral Oncol 49: 306-313, 2013.

60. Yu S, Cai X, Wu C, Wu L, Wang Y, Liu Y, Y, et al: Adhesion glycoprotein CD44 functions as an upstream regulator of a network connecting ERK, AKT and Hippo-YAP pathways in cancer progression. Oncotarget 6: 2951-2965, 2015.
61. Sawai M, Yashiro M, Nishiguchi Y, Ohira M and Hirakawa K: Growth-inhibitory effects of the ketone body, monoacetoacetin, on human gastric cancer cells with succinyl-CoA: 3-oxoacid CoA-transferase (SCOT) deficiency. Anticancer Res 24: 2213-2217, 2004

62. Martinez-Outschoorn UE, Lin Z, Whitaker-Menezes D, Howell A, Sotgia F and Lisanti MP: Ketone body utilization drives tumor growth and metastasis. Cell cycle 11: 3964-3971, 2012.

63. Saraon P, Cretu D, Musrap N, Karagiannis GS, Batruch I, Drabovich AP, van der Kwast T, Mizokami A, Morrissey C, Jarvi K and Diamandis EP: Quantitative proteomics reveals that enzymes of the ketogenic pathway are associated with prostate cancer progression. Mol Cell Proteomics 12: 1589-1601, 2013.

64. Mourtada-Maarabouni M, Watson D, Munir M, Farzaneh F and Williams GT: Apoptosis suppression by candidate oncogene PLAC8 is reversed in other cell types. Curr Cancer Drug Targets 13: 80-91, 2013.

65. Li C, Ma H, Wang Y, Cao Z, Graves-Deal R, Powell AE, Starchenko A, Ayers GD, Washington MK, Kamath V, et al: Excess PLAC8 promotes an unconventional ERK2-dependent EMT in colon cancer. J Clin Invest 124: 2172-2187, 2014.

66. Coghlin C and Murray GI: Biomarkers of colorectal cancer: Recent advances and future challenges. Proteomics Clin Appl 9: 64-71, 2015

67. Okuno K, Yasutomi M, Nishimura N, Arakawa T, Shiomi M, Hida J, Ueda K and Minami K: Gene expression analysis in colorectal cancer using practical DNA array filter. Dis Colon Rectum 44: 295-299, 2001.

68. Kim HJ, Yu MH, Kim H, Byun J and Lee C: Noninvasive molecular biomarkers for the detection of colorectal cancer. BMB Rep 41: 685-692, 2008

69. Zoratto F, Rossi L, Verrico M, Papa A, Basso E, Zullo A, Tomao L, Romiti A, Lo Russo G and Tomao S: Focus on genetic and epigenetic events of colorectal cancer pathogenesis: Implications for molecular diagnosis. Tumour Biol 35: 6195-6206, 2014. 